\title{
Growth Performance of the Mudfish, Clarias anguillaris (Pellegrin, 1923) in Treated and Untreated Domestic Sewage
}

\author{
Agatha A. Nwabueze ${ }^{1}$ \\ ${ }^{1}$ Department of Fisheries Delta State University, Asaba Campus, Asaba, Nigeria \\ Correspondence: Agatha A. Nwabueze, Department of Fisheries Delta State University, Asaba Campus, Asaba, \\ Nigeria. E-mail: arimiche@yahoo.com
}

Received: July 31, 2012 Accepted: September 4, 2012 Online Published: October 10, 2012

doi:10.5539/sar.v2n1p62 URL: http://dx.doi.org/10.5539/sar.v2n1p62

\begin{abstract}
Growth of the mudfish, Clarias anguillaris in of treated and untreated domestic sewage was investigated. Six weeks old fingerlings obtained from Delta State University, Asaba Campus Research Farm were used and the study lasted for 14 weeks. Fingerlings were kept in stock tank containing $10,000 \mathrm{~cm}^{3}$ bore hole water and allowed to acclimate for two weeks. The stock tank was well aerated and fingerlings fed twice daily at the rate of $4 \%$ body weight with poultry mash in a daily renewal static bioassay system. The stock ( $0 \%$ - control) was then diluted with bole hole water serially to give $25,50,75 \%$ strength of the treated and untreated domestic sewage and $100 \%$ into which 10 fingerlings each were introduced. Weekly measurement of growth parameters of fish total length and weight were taken. The condition factor $(\mathrm{k})$ was calculated. Increase in fish total length and weight in control, treated and untreated domestic sewage was observed. Growth of fish was significantly higher $(\mathrm{P}<0.05)$ in the treated domestic sewage than in the untreated. There was no significant $(\mathrm{P}>0.05)$ difference in total length of fish in all concentrations of treated domestic sewage as compared with controls. However, fish in $100 \%$ concentration of domestic sewage had a slower increase in total length than fish in other treated concentrations. Weight gain in $C$. anguillaris was higher in the $50 \%$ but not significantly $(\mathrm{P}>0.05)$ higher than other concentrations of treated domestic sewage. The increase in fish weight in the untreated domestic sewage was not significantly $(\mathrm{P}>0.05)$ different in all the treatments but was significantly $(\mathrm{P}<0.05)$ lower than that of fish in the control. Condition factor of $C$. anguillaris in both the treated and untreated domestic sewage varied and decreased except for fish in $100 \%$ treated domestic sewage which was observed to have an increase in the value of the condition factor from $3.76 \mathrm{~g} \mathrm{~cm}^{-3}$ to $4.73 \mathrm{~g} \mathrm{~cm}^{-3}$. Untreated domestic sewage water showed a higher turbidity, biochemical Oxygen Demand (B.O.D), alkalinity and nitrate composition of than treated sewage which had higher oxygen content and was clearer in appearance than the untreated. Microbial analysis shows the presence of Escherichia fecalis, Streptococcus fecalis and Enterococcus fecalis in untreated sewage with ciliated protozoans in both treated and untreated sewage. This study has shown that treated domestic sewage is best for healthy fish growth with reduced risk of transfer of pathogens.
\end{abstract}

Keywords: domestic sewage, fish growth, Clarias anguillaris

\section{Introduction}

Domestic sewage is water-borne human waste and is a combination of water and waste removed from residences, institutions, commercial and industrial establishments together with ground water, surface water and storm water. Malik and Ahmed (2004) reported that the composition of sewage varies depending on the source of waste water and this also causes a variation in the microbial flora of sewage. Domestic waste may contain human waste as faecal materials, food waste and wash water while industrial waste contain acids, oils, grease, animal and vegetable matter discharged by factories (Cointreau, 2006). Domestic sewage may contain nutrient which may stimulate growth of aquatic plants (Allen, 1985) and enhance production of natural food for fish.

The use of domestic sewage for fish culture has been an age long technique widely used to meet the growing demand for fish. Sondhia (2008) reported that sewage water reduces the cost of fish production by substituting chemical fertilizers and costly feeds while providing useful nutrients recycled which encouraged fish growth. However, the increase in pond productivity results in oxygen depletion due to bacterial oxygen demand caused by an increase in organic load. The presence of pathogenic microbes in human excreta may also cause public health hazards in aquaculture (Strauss, 1991). Treatment of domestic waste water has been advocated to 
minimize oxygen depletion and presence of pathogenic microbes in aquacultural systems. Various treatment procedures have been employed in the treatment of domestic sewage (Jena et al., 2010, Okomoda et al., 2012).

Treatment and proper disposal of domestic wastewater is not only desirable but also necessary in any society. In view of the use of domestic sewage in fish culture, there is a need to consider the effect of treated and untreated domestic sewage on growth performance of pond fish, hence the aim of this research.

\section{Materials and Methods}

\subsection{Study Area}

The study was conducted in the Department of Fisheries Laboratory, Delta State University, Asaba Campus, Asaba. Asaba is located on longitude $6^{\circ} 11^{\prime} \mathrm{E}$ and latitude $6^{\circ} 45^{\prime} \mathrm{N}$ in the rain forest zone of southern Nigeria. The study which was carried out for 14 weeks lasted from January to April, 2009.

\subsection{Collection of Samples}

Six weeks old fingerlings of Clarias anguillaris mudfish ranging in total length from 5.8 to $7.1 \pm 0.83 \mathrm{~cm}$ and weight from 10.55 to $20.30 \mathrm{~g} \pm 4.69$ obtained from Delta State University, Asaba Campus Research farm were used. Domestic sewage water was collected from bathroom/toilet and kitchen water pipes of some indigenous residence in Asaba.

\subsection{Acclimation}

Fingerlings were kept in stock tank containing $10,000 \mathrm{~cm}^{3}$ bore hole water and allowed to acclimate for two weeks. Fingerlings were fed twice daily $(10.00 \mathrm{am}$ and $6.00 \mathrm{pm})$ at the rate of $4 \%$ body weight with poultry mash in a daily renewal static bioassay system.

\subsection{Experimental Design}

The stock ( $0 \%$ - control) was then diluted with bole hole water serially to give $25,50,75 \%$ strength of the treated and untreated domestic sewage. The mixture was allowed to stand for three hours to obtain a clear interphase between the sewage and diluent before the introduction of fingerlings. Ten fingerlings each were kept in 8 aquaria, 4 each of which contained 25, 50, 75 and $100 \%$ treated and untreated domestic sewage respectively. The experiment was laid out in a randomized complete block design (RCBD) with five treatments each $(0 \%$ control, 25, 50, 75 and $100 \%$ ) of treated and untreated domestic sewage and weekly exposure time. Daily renewal of the bole hole water with the treated and untreated domestic water fractions was done and weekly measurements of growth parameters of total length $(\mathrm{cm})$ and weight $(\mathrm{g})$ of fish were taken.

\subsection{Condition Factor (K)}

The condition factor $(\mathrm{K})$ was calculated according to the equation (Le-Cren, 1951):

$\mathrm{K}=100 . \mathrm{W} / \mathrm{L}^{3}$

where $\mathrm{W}$ is fish body weight $(\mathrm{g})$ and $\mathrm{L}$ is fish total length $(\mathrm{cm})$

\subsection{Treatment of Sewage}

Chemical treatment of domestic water was done by chlorination at the laboratory of Delta State Urban Water Board using $2.5 \mathrm{~g}$ of sodium hypochloride in 20 liters of water.

\subsection{Analysis of Data}

Analyses of treated and untreated domestic wastewater parameters such as appearance, qualitative taste and odour, colour, $\mathrm{pH}$, acidity, alkalinity, turbidity, chloride, nitrate, biochemical oxygen demand (B.O.D.), dissolved oxygen (D.O) were determined using the method of APHA (1985). Data obtained were subjected to analysis of variance (ANOVA) at $\mathrm{P}<0.05$ level of significance. Significant means were separated with Duncan Multiple Range Test (DMRT) using SAS (1996).

\section{Results}

\subsection{Growth of Clarias anguillaris}

Increase in fish total length and weight in control, treated and untreated domestic sewage was observed. Fish growth was found to be higher in the treated domestic sewage as compared with fish growth in untreated and control set ups. There was no significant $(\mathrm{P}>0.05)$ difference in total length of fish in all concentrations of treated domestic sewage as compared with controls. However, fish in $100 \%$ concentration of domestic sewage had a slower increase in total length than fish in other treated concentrations (Figure 1). Fish in all concentrations of untreated sewage increased in total length but fish in $25 \%$ increased slightly more than the others (Figure 2). 
Weight gain in $C$. anguillaris was higher in the $50 \%$ but not significantly $(\mathrm{P}>0.05)$ higher than other concentrations of treated domestic sewage. Fish in $25 \%, 50 \%$ and $75 \%$ of treated domestic sewage and control did not differ significantly $(\mathrm{P}>0.05)$. Figure 3 shows the initial and final weight of $C$. anguillaris in treated domestic sewage. The increase in fish weight in the untreated domestic sewage was not significantly $(\mathrm{P}>0.05)$ different in all the treatments but was significantly $(\mathrm{P}<0.05)$ lower than that of fish in the control (Figure 4). Growth performance in total length and weight of $C$. anguillaris in treated and untreated domestic sewage are presented in Figures 5 and 6.

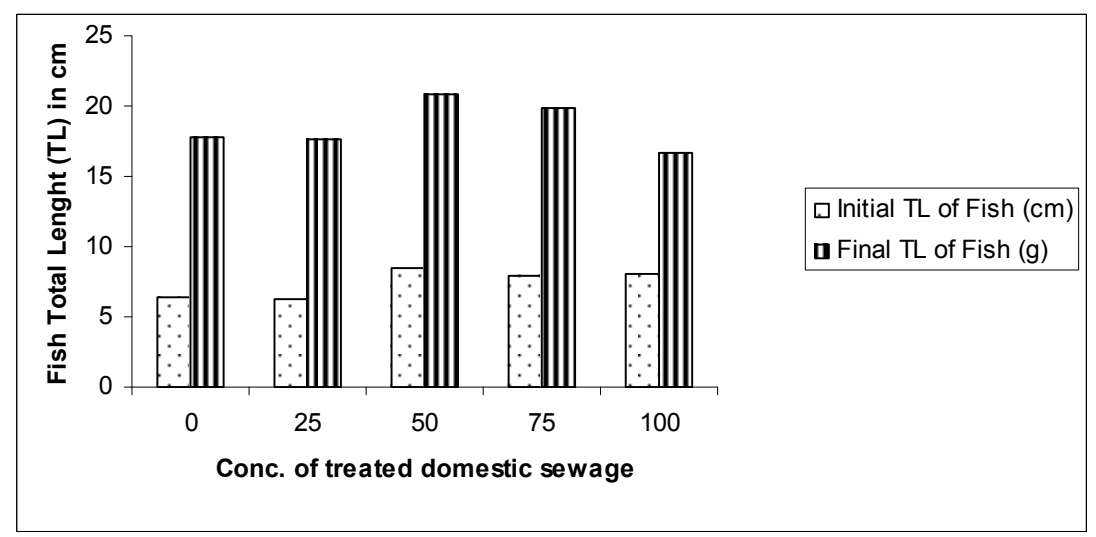

Figure 1. Initial and final total length of C. anguillaris in treated domestic sewage

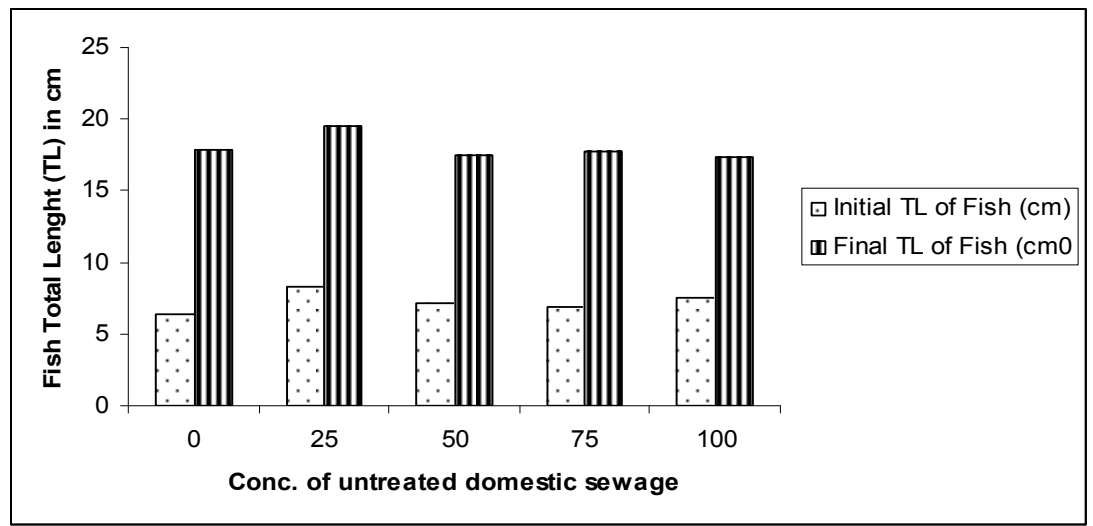

Figure 2. Initial and final total length of $C$. anguillaris in untreated domestic sewage

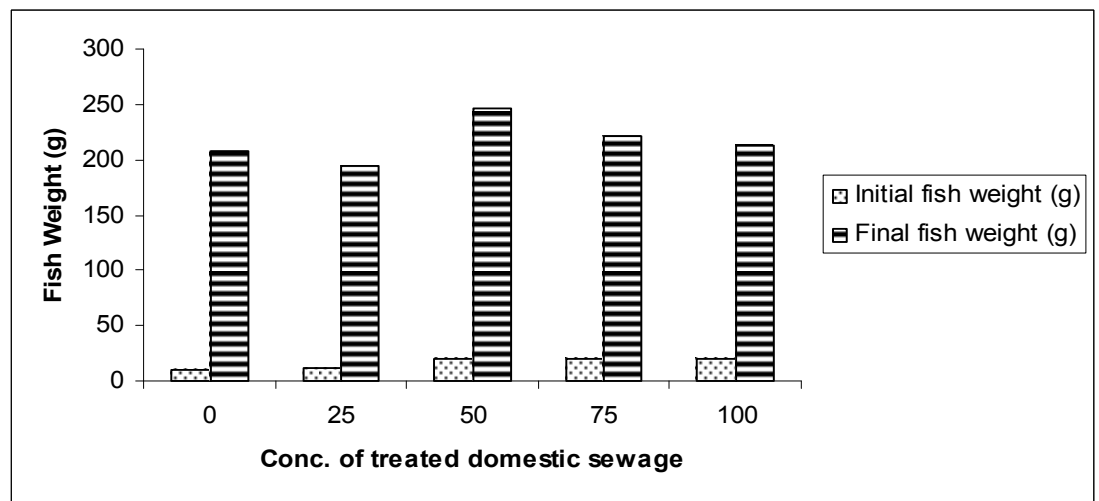

Figure 3. Initial and final weight of $C$. anguillaris in treated domestic sewage 


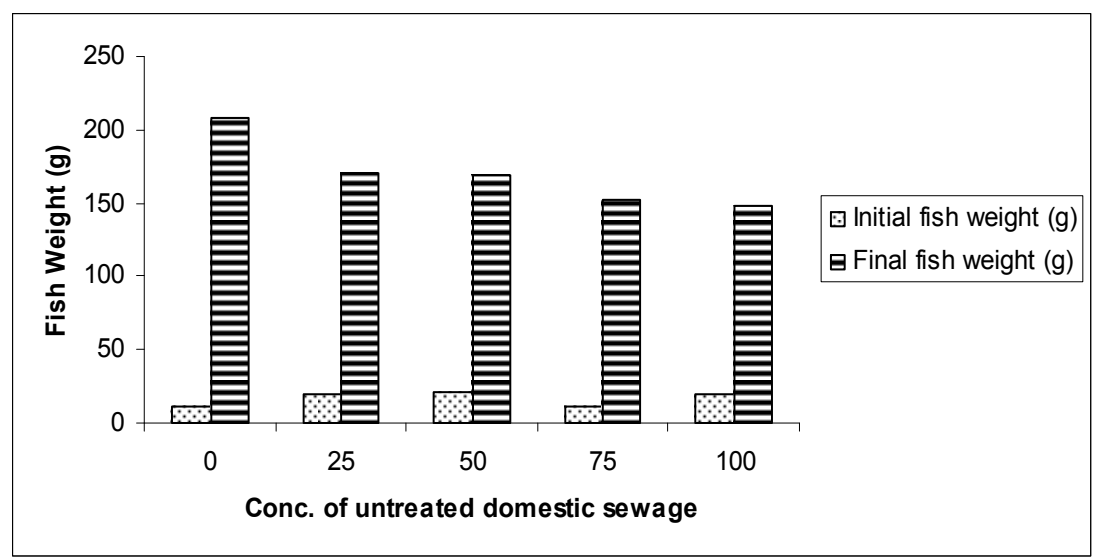

Figure 4. Initial and final weight of $C$. anguillaris in untreated domestic sewage

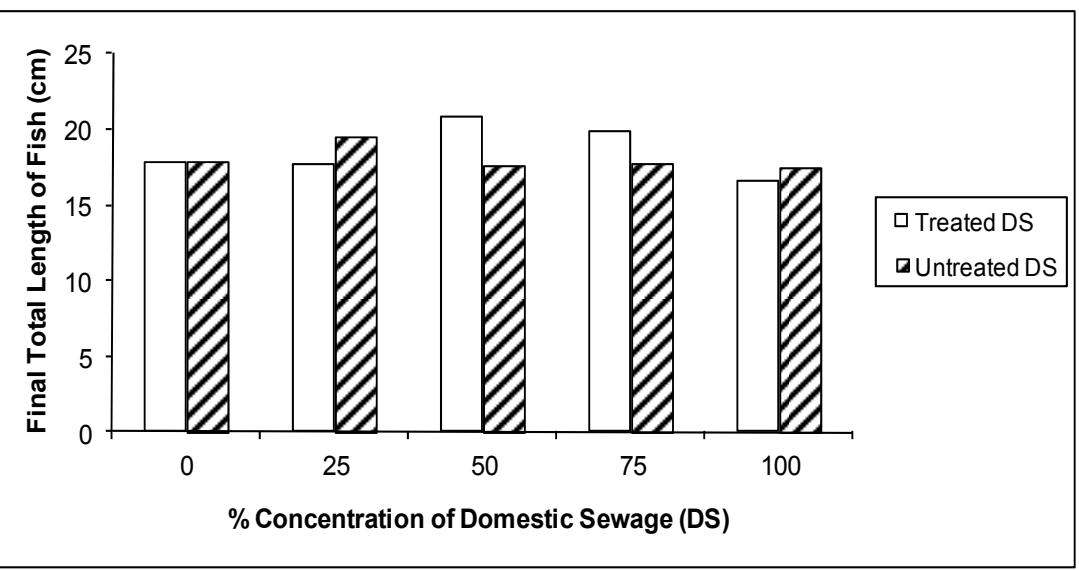

Figure 5. Growth performance in total length of C.anguillaris in treated and untreated domestic sewage

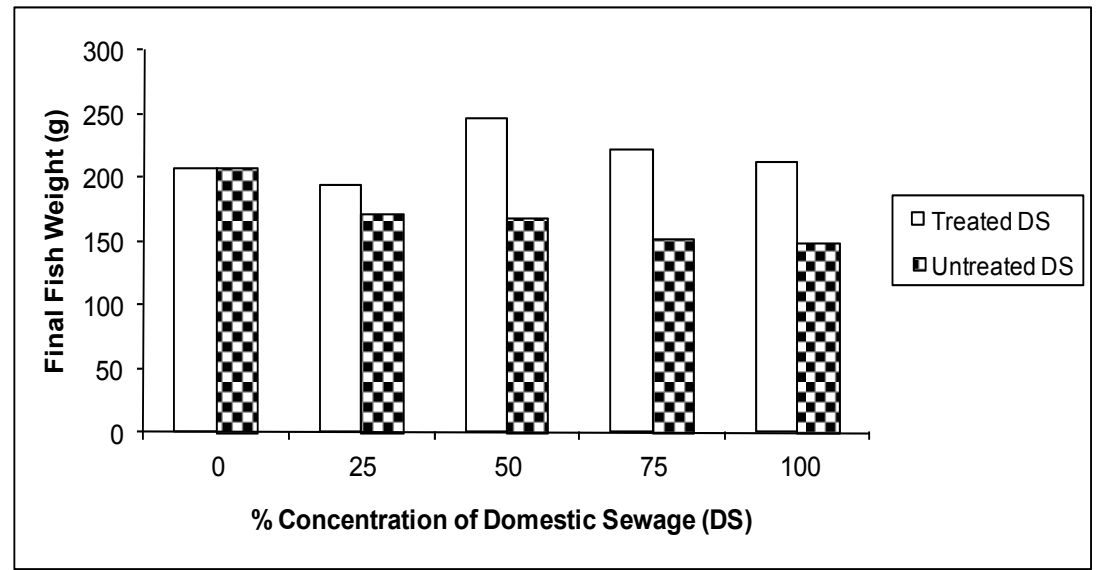

Figure 6. Growth performance in weight of C.anguillaris in treated and untreated domestic sewage

\subsection{Condition Factor $(K)$}

There was a general decrease in condition factor of $C$. anguillaris in both the treated and untreated domestic sewage except for fish in $100 \%$ treated domestic sewage which was observed to have an increase in the value of 
the condition factor from $3.76 \mathrm{~g} \mathrm{~cm}^{-3}$ to $4.73 \mathrm{~g} \mathrm{~cm}^{-3}$. The condition factor $(\mathrm{K})$ for $C$. anguillaris in all treatment groups and control is presented in Table 1.

Table 1. Initial and final values of condition factor $(\mathrm{K})$ of $C$. anguillaris in treated and untreated domestic sewage

\begin{tabular}{cccc}
\hline Domestic Sewage & $\%$ & Initial $\mathrm{K}\left(\mathrm{g} \mathrm{cm}^{-3}\right)$ & Final $\mathrm{k}\left(\mathrm{g} \mathrm{cm}^{-3}\right)$ \\
\hline Treated & 0 & 4.12 & 3.68 \\
& 25 & 4.57 & 3.51 \\
& 50 & 3.31 & 2.75 \\
& 75 & 4.10 & 2.81 \\
Untreated & 100 & 3.76 & 4.73 \\
& 0 & 4.12 & 3.68 \\
& 25 & 3.52 & 2.30 \\
& 50 & 5.67 & 3.14 \\
& 75 & 3.23 & 2.75 \\
& 100 & 4.74 & 2.80 \\
\hline
\end{tabular}

Table 2. Results of treated and untreated sewage water parameters used for the growth of C. anguillaris

\begin{tabular}{ccc}
\hline Sample Parameter & Treated & Untreated \\
\hline Appearance & Clear & Opaque \\
Qualitative Taste & Pleasant & Unobjectionable \\
Qualitative Odour & Natural & Unobjectionable \\
Colour & $0.5 \mathrm{~Hz}$ & $10.0 \mathrm{~Hz}$ \\
pH & 7.0 & 7.6 \\
Acidity & 6.0 & 5.5 \\
Alkalinity (mg/l) & 7.2 & 8.2 \\
Turbidity (n.t.u) & 30.0 & 50.0 \\
Chloride (mg/l) & 3.0 & 0.3 \\
Nitrate (mg/l) & 0.01 & 0.1 \\
B.O.D. (mg/l) & 30.0 & 50.0 \\
Dissolved Oxygen (mg/l) & 4.81 & 2.58 \\
\hline
\end{tabular}

Table 3. Microbial composition of treated and untreated domestic sewage

\begin{tabular}{ccc}
\hline Sample Parameter & Treated & Untreated \\
\hline Total Microbial Load $\left(10^{3} \mathrm{cfug}^{-1}\right)$ & - & 5.0 \\
Coliform $\left(10^{3} \mathrm{cfug}^{-1}\right)$ & - & 3.0 \\
Bacteria Isolated & - & E. fecalis \\
& - & S. fecalis \\
Protozoa & Ciliated Protozoan & Ciliated Protozoan \\
\hline
\end{tabular}

\subsection{Water Quality Parameters}

Analysis of treated and untreated domestic sewage water showed a higher turbidity, biochemical Oxygen 
Demand (B.O.D), alkalinity and nitrate composition of untreated domestic sewage. Whereas treated domestic sewage had higher oxygen content than the untreated sewage and was clearer in appearance. Fish in treated domestic sewage was observed to have a more positive response to feeding than fish in untreated sewage. Table 2 shows the mean values of treated and untreated domestic sewage water parameters.

\subsection{Microbial Composition}

Microbial analysis of untreated domestic sewage shows the presence of Escherichia fecalis, Streptococcus fecalis, Enterococcus fecalis and unidentified ciliated protozoan (Table 3). Only ciliated protozoan was found in the treated domestic sewage. Cilliated protozoan was found in both treated and untreated domestic sewage.

\section{Discussion}

A significant increase in fish growth was observed in treated domestic sewage than in untreated. Total length of fish increased with increasing period of exposure in all experimental groups. Total length of fish had an increasing sequence of growth in $100 \%<25 \%<75 \%<50 \%$ concentrations of treated and $100 \%<50 \%<75 \%<25 \%$ of untreated sewage. Fish weight had an increasing sequence of growth in $25 \%<100 \%<75 \%<50 \%$ concentrations of treated and $100 \%<75 \%<50 \%<25 \%$ of untreated sewage. The higher growth observed in the fish in the treated domestic sewage could be attributed to increased efficiency utilization of feeds in the treated sample. Treated domestic sewage had reduced organic matter which was desirable for availability of dissolved oxygen needed by fish. Treated domestic wastewater has been reported to have little or no microbial load (Little \& Edward, 2003). This may have prevented oxygen depletion by bacterial action (Strauss, 1991) and enhanced fish growth. Higher fish growth has also been reported in biologically treated fish ponds (Jena et al., 2010).

The condition factor, which is a manifestation of body condition, was found to be higher for fish in treated sewage than in untreated sewage. Condition factor of C. anguillaris varied in all the treatment groups. According to Bagenal and Tesch (1978), the condition factor is a length-weight relationship that indicates the well-being of the fish. William (2000) also reported that the condition factor of fish indicates the relative robustness, or degree of well-being of a fish and that it varies depending on the state of sexual maturity and degree of nourishment as well as with fish age, and in some species, with sex. Variation in condition factors of fish according to King (1995) may be indicative of food abundance, adaptation to the environment and gonadal development. A high value indicates a period of increased rate of feeding, followed by a gradual increase in accumulated fat suggesting a preparation for a new reproductive period. The condition factor $(\mathrm{K})$ has been closely linked with reproductive cycle of fish (Fagade \& Olaniyan, 1972; Aboaba, 1993).

Treated domestic sewage had more light penetration as evidenced by the lower turbidity observed enabling fish have easy access to food. The reduced B.O.D also corroborate reduced organic load in the treated water sample. According to Maduka (2005) B.O.D. is a sign of organic pollution and causes suffocation of fish and other aquatic animals due to high oxygen demand by microbes. The water parameters of the treated and untreated domestic sewage were within the range to accommodate fish survival in fish culture systems (Boyd, 1989). The nitrate balance concentration has been noted to reduce physiological distress while Howerton (2001), reported that chloride impacts a good range of salty taste reducing physiological damage to fish. Gietema (1992) reported that high turbidity of water reduces light penetration hence photosynthesis causing a drop in the $\mathrm{pH}$ which is detrimental to aquatic life.

Escherichia fecalis, Streptococcus fecalis and Enterococcus fecalis have been identified in association with domestic effluent discharges into the environment (Okoronkwo \& Odeyemi, 1985; Ekhaise \& Anyasi, 2005). Escherichia coli has been reported as a common pathogen associated with fish due to the nature of fish environment (Guzman et al., 2004). Fish are more susceptible to disease or infection where water quality is marginal and fish exposed to environmental stress factors (Snieszko, 2006). This is not unusual as Christine and Hose (1993) reported that ciliated protozoans can survive chlorination and any other disinfecting method except for filtration techniques. The presence of ciliated protozoan further shows that treatment cannot completely eliminate microbes but can only reduce the microbial load. Natural ponds have been found to be one of nature's most economic treatment systems for pathogens present in organic wastes. Little and Edward (2003) reported that shallow tropical fish ponds tend to cause rapid attenuation of pathogens. Ponds though are capable of self purification to some extent, Ducklow (1983) noted that the process is much more slower than packaged treatment plants. This study has shown that fish cultured in treated domestic sewage had the highest growth rate. Treated domestic sewage is recommended for fish culture because it is beneficial in promoting healthy fish growth with reduced risk associated with the transfer of pathogens. 


\section{References}

Aboaba, M. A. (1993). Reproduction, larval rearing and the influence of dietary protein on the growth of the catfish (Chrysichthys nigrodigitatus) Ph.D Thesis, University of Ibadan, Ibadan, Nigeria.

Allen, G. H. (1985). A preliminary bibliography on the utilization of sewage in fish culture. FAO fish circle. p. 308.

APHA. (1985). Standard methods for the examination of water and wastewater (10th ed.). American Public Health Association, Washington D.C. p.1268

Bagenal, T. B., \& Tesch, F. W. (1978). Age and growth: In: Bagenal, T.B. (Ed.). Methods of assessment of fish production in fresh waters. Blackwell Scientific Publications, Oxford. pp. 101-136.

Boyd, C. E. (1989). Water Quality Management and Aeration in shrimp farming. Auburn University Alabama

Agriculture Experimental Station Department. Series No. 2.

Christine, M., \& Hose, A. (1993). Pathogenic Vibrio in the natural aquatic environment. Review of Environmental Health, 12, 63-80.

Cointreau, S. (2006). Occupational and Environmental Health Issues of Solid Waste Management: Special Emphasis on Middle- and -Lower-income countries. Urban Papers. 2. This World Bank Group. Washington, D.C.

Ducklow, H. N. (1983). Production and rate of bacteria in the ocean. Bioscience, 33, 494-501. http://dx.doi.org/10.2307/1309138

Ekhaise, F. O., \& Anyasi, C. C. (2005). Influence of breweries effluent discharge on the microbiological and physicochemical quality of Ikpoba River, Nigeria. African Journal of Biotechnology, 4(10), 1062-1065.

Fagade, S. O., \& Olaniyan, C. I. O. (1972). The biology of the West African Shad, Ethmalosa fimbriata (Bowdich) in the Lagos Lagoon, Nigeria. Journal of Fish Biology, 4, 519-533. http://dx.doi.org/10.1111/j.1095-8649.1972.tb05699.x

Gietema, B. (1992). Fish farming in ponds and integrated farming. Gbemi Sodipo Press Ltd., Abeokuta, Nigeria. p. 143.

Guzman, M. C., Bistoni, M., Tamagnini, L. M., \& Gonzales, R. O. (2004). Recovery of E. coli in fresh water fish, Jenynsia multidentata and Bryconamericus iheringi Water Research, 38(9), 2368-2374. http://dx.doi.org/10.1016/j.watres.2004.02.016

Howerton, R. (2001). Best Management Practices for Hawaii Aquaculture. Centre for Tropical and Subtropical Aquaculture Publication no.148. University of Hawaii Sea Grant Extension Services.

Jena, J. K., Patro, B., Patri, P., Khuntia, C. P., Tripathy, N. K., Sinha, S., Sarangi, N., \& Ayyappan, S. (2010). Biological Treatment of Domestic Sewage through Duckweed-cum-fish Culture: A Pilot-scale Study. Indian Journal of Fisheries, 57(4), 45-52.

King, M. (1995). Fisheries Biology, Assessment and Management. Fishing News Books, Oxford, p. 39.

Little, D. C., \& Edward, P. (2003). Integrated Livestoch-fish farming systems. 6. Public Health and Livestock-fish. FAO Corporate Document Repository, p.189.

Maduka, H. C. (2005). Water Pollution and Man's Health. The Interment Journal of Gastroenterology, 4(1), $1-13$.

Malik, A., \& Ahmed, M. (2004). Seasonal variation in Bacterial Flora of the Waste Water and Soil vicinity of Industrial area. Environmental Monitoring and Assessment, 73(3), 263-273. http://dx.doi.org/10.1023/A:1013186218093

Okomoda, V. T., Solomon, S. G., \& Ataguba, G. A. (2012). Potential Uses of The Family Lemnacae. Journal of Agriculture and Veterinary Sciences, 4, 1-14.

Okoronkwo, N., \& Odeyemi, O. (1985). Effect of a sewage Lagoon effluent on the water quality of the receiving stream. Environmental Pollution. Series A, 37, 71-86. http://dx.doi.org/10.1016/0143-1471(85)90025-X

SAS. (1996). SAS User's Guide: Statistics Version 5, Vol. 2. Raleigh. U.S.A. p. 1687.

Snieszko, S. F. (2006). The effects of environmental stress on outbreaks of infectious diseases of fish. Journal of Fish Biology, 6(2), 197-208. http://dx.doi.org/10.1111/j.1095-8649.1974.tb04537.x 
Sondha, S. (2008). Evaluation of Sewage-Fed Fisheries in Terms of water quality Risk of Heavy metal contamination and Fish Yield. (Sengupta, M. \& Dalwani, R. Editions), Proceedings of Taal 2007: The $12^{\text {th }}$ World Lake Conference, pp.165-166.

Strauss, M. (1991). Human waste use: Health protection practices and scheme monitoring. Water Science Technology, 24(9), 67-79.

Williams, J. E. (2000). The Coefficient of Condition of Fish. Chapter 13 in Schneider, James, C. (ed.) 2000. Manual of fisheries survey methods II: with periodic updates. Michigan Department of Natural Resources, Fisheries Special Report 25, Ann Arbor. 